\title{
Introduction: entrepreneurship, competitiveness and local development
}

\author{
Luca Iandoli, Hans Landström and Mario Raffa
}

\section{INTRODUCTION}

The Research in Entrepreneurship (RENT) conference is an annual international research meeting for scholars and practitioners in the field of entrepreneurship and small business management, promoted by the ECSB (European Council for Small Business and Entrepreneurship) and the EIASM (European Institute for Advanced Studies in Management). Starting from the RENT conference in Copenhagen in 2004, an anthology containing the best papers presented at RENT conferences is published yearly thanks to the joint effort of the RENT Scientific Committee and the local conference organizers. This book in particular contains a group of 11 contributions selected among the 131 accepted for presentation at the RENT conference hosted at the University Federico II in Naples (Italy) in November 2005. The anthology is representative of the main research areas that are of interest to a community of scholars, which is undoubtedly the leading research community in entrepreneurial and small business studies in Europe and one of the most representative ones at the international level.

The RENT conference has undergone a remarkable growth during the last 20 years. As a consequence it has experienced a marked increase in heterogeneity of approaches, research topics and theoretical backgrounds. This increasing diversity undoubtedly represents a valuable resource. At the same time a need for a unitary view and the search for point of contacts between different approaches seems to emerge. As with any growing and evolving research field, entrepreneurship studies also need to manage a trade-off. It is necessary to preserve internal diversity to foster innovation and at the same time to find a common background, shared values and a common language to ensure that the different research 'souls' are able to talk to each other and cross-fertilize the debate. In our opinion, two possible directions to manage this trade-off have been proposed at the 2005 RENT conference. 
The first is related to the conference theme: 'Entrepreneurship, Competitiveness and Local Development'. In the following we present some considerations about the relationship between entrepreneurship and local development, and introduce a competence-based framework to entrepreneurship aimed at proposing a unitary view of some of the main research challenges for sustaining small firms and local development.

The second direction was addressed by Hans Landström from Lund University in his keynote speech, when he outlined the long history of entrepreneurship as a research discipline, identified the most influential thinkers on entrepreneurship research and argued that a more coherent picture and unitary view of entrepreneurship can be gained if one looks at its roots and evolution. In other words, he claims that history matters and in order to move the field of entrepreneurship research forward we need to look backward.

The next section contains a summary of Landström's speech. Then we outline the main research topics addressed in the papers presented at the 2005 conference through a competence-based framework to entrepreneurship research for local development. Finally we illustrate the organization of the book and present the chapters contained in this anthology.

\section{A HISTORY OF ENTREPRENEURSHIP RESEARCH}

This historical retrospect will start with a short summary of early thinking on entrepreneurship leading to a discussion about Joseph Schumpeter - his thoughts and life. Next, the change of entrepreneurship research from a topic within the discipline of economics to a behavioural science, with David McClelland as one of the pioneering exponents for this new approach, will be elaborated. Finally, the emergence of a research field of its own will be discussed: the turbulence in society during the 1960s and 1970s, the seminal work by David Birch, and the characteristics of entrepreneurship as an emergent field of research.

\section{Early Thinking on Entrepreneurship}

Despite its relatively recent ascent to acceptance as an academic field, entrepreneurship research has a long tradition (Landström, 2005). Although the term 'entrepreneur' has been used in the French language since the twelfth century, the feudal system operating in the European world at the time hampered the development of entrepreneurship and innovation. Gradually, during the Middle Ages, the situation changed, especially in countries such as Italy, France and southern Germany, which became the driving forces 
behind European economic development. Emerging cities created a breeding ground for entrepreneurship, especially among the merchant class who processed raw material and marketed the finished goods. By the eighteenth century, feudalism had been eliminated, and legal and institutional conditions had greatly changed with the burgeoning of the joint stock company and the development of a banking system (Wennekers and Thurik, 1999). Entrepreneurship and innovation thrived.

It was the writings of the Irish-born banker (who lived in Paris), Richard Cantillon (circa 1680-1734), whose Essai Sur la Nature du Commerce en Général was published posthumously in 1755 , that gave the concept of entrepreneurship an economic meaning and the entrepreneur a role in economic development. However, for a long period 'classical' economic theory, originating in Adam Smith's well-known work Inquiry into the Nature and Causes of the Wealth of Nations (1776 [1994]), dominated the intellectual development of economic science - an economic theory that did not emphasize the entrepreneurial function in the economy. Only a few economists were successful in breaking that trend, and authors such as JeanBaptiste Say (1767-1832), Jeremy Bentham (1748-1832) and John Stuart Mill (1806-73) should be mentioned in this respect.

At the end of the nineteenth century, the European discussion of entrepreneurship found an audience in the United States, which by that time was well on the way to becoming a major industrial power. Some of the American economists who developed the discussion about entrepreneurship during this period were Francis Walker, Fredrick Hawley and John Bates Clark. Perhaps the best-known author among them was Frank Knight (1885-1972), who in his thesis Risk, Uncertainty and Profit (1916, revised 1921) makes a distinction between risk and uncertainty, where uncertainty is unique and uninsurable and he argues that the skills of the entrepreneur lie in the ability to handle the uncertainty that exists in any given society.

\section{Joseph Alois Schumpeter}

The late nineteenth and early twentieth centuries were characterized by the emergence of an industrial society, and the building of the modern enterprise. Many authors claimed to see the death of small firms in the economy. It was against this background that the thoughts of Joseph Schumpeter (1885-1950) were developed. Schumpeter was inspired by Gustav Schmoller, who in his analysis of the historical-economic development, was convinced that there existed a unique and central factor in all economic activity the entrepreneur - who is a key figure due to his/her ability as a creative organizer. Schumpeter's seminal work was Theorie der Wirtschaftlichen 
Entwicklung (1912, second edition 1926) or The Theory of Economic Development (1934), which is the English translation of the second edition. The first and second editions are rather different, in that the latter is more streamlined and Schumpeter attempted to relate his work to the mainstream of economic thinking at that time. In the book, Schumpeter tried to develop an entirely new economic theory based on change - as opposed to equilibrium. The basic assumption was that economic growth resulted not from capital accumulation but from innovations, or 'new combinations'. Once Schumpeter had recognized the crucial role of innovation in economic growth, he understood that innovation had to be implemented by someone, and this ability to break the established practice was primarily related to the individual entrepreneurs. In Chapter 2 of the book, he discusses the function of the entrepreneur as an individual who tends to break the market's equilibrium by introducing innovations into the system - entrepreneurs who were characterized by the desire and the will to found private kingdoms (power and independence), the will to conquer (succeed) and the joy of creating (getting things done).

Schumpeter was highly productive: during his career he wrote nine major books, more than 200 papers and 90 book reviews. If we look at his production of scientific works it could be regarded as very fragmented, but throughout his career there is a very clear line of thought - to build a new economic theory built on 'newness'. It might also be important to put this idea into the context of his career and his life (Box I.1).

All his misfortunes, not least during the 1920s - his abrupt dismissal as finance minister in Austria, his own financial problems as a consequence of too risky investments, and the fact that his mother died in 1926, followed a couple of months later by his wife and son (Josef) - made him very pessimistic and melancholic, and to some extent self-destructive. His wife and mother became a personal cult, and he buried himself in his work and much travelling.

Schumpeter is often regarded as difficult to understand. One reason for this is that he was a very bad pedagogue - his arguments were not always easy to follow, and he wrote in a rather complex way (for example he seldom cited other authors, he used long sentences, and he defined his terms explicitly). He was also to a considerable extent a 'one-man band' in the sense that he was never part of a 'school of thought' and he had no followers among his PhD students.

It should be added that Schumpeter never received any strong recognition among economists, and his influence on policy was rather limited - he was totally absorbed by the Keynesian revolution in 1936 and Keynes's General Theory of Employment, Interest and Money (1936). Keynes's reasoning was more normative and emphasized to a greater extent the role 


\section{BOX I.1 THE CAREER OF JOSEPH SCHUMPETER}

1883 Born an only child on 8 February in Triesch (today in Slovakia). His father was a factory owner, but died when Joseph was four years old

1893 Joseph and his mother moved to Vienna

1901-06 Study of Law and Economics at the University of Vienna Several of the world's most famous economists were working at the Department of Law at that time, such as Carl Menger, Eugen von Böhm-Bawerk, Friedrich von Wieser and Gustav Schmoller

1906 Doctorate (Dr Juris) in Law (23 years old)

1906 Post-doctorate at London School of Economics

1907-08 Practised law at the International Mixed Tribunal in Cairo 1909 Associate Professor ('habilitation' degree) at the University of Vienna

1909-11 Teacher in economics at the University of Chervotsky (Ukraine)

1911-21 Professor at the University of Graz

1913-14 Visiting Professor at Columbia University in New York

1919 Finance minister in a Social Democratic government in Austria, but was abruptly replaced after seven months

1921-24 President of the Biedermann Bank in Vienna Used his wealth to invest in outside speculations, but during the crisis of 1924 in Austria the bank failed and he became bankrupt

1925-32 Professor of Economics at the University of Bonn

1926 His mother died (in June), and his wife and son died in childbirth (in August)

1927-28 Visiting Professor at Harvard University

1931 Visiting Professor at Tokyo College of Commerce

1932-50 Professor of Economics at Harvard University

1939 Became an American citizen

Schumpeter had a very conservative political attitude. At the outbreak of the Second World War, the FBI investigated him for pro-Nazi leanings, but there was no evidence that he had any sympathies for Nazism

1950 Died on the night of 7-8 January 1950, at the age of 66

Sources: Swedberg (1994); Reisman (2004). 
of the government, and the Great Depression during the 1930s made Schumpeter's theory irrelevant and even wrong.

However, Schumpeter's reasoning has remained a basic point of reference for many of his successors, both those who follow his tradition of regarding the entrepreneur as an innovative pathbreaker (for example, Dahmén, 1950; Leibenstein, 1968; Baumol, 1968, 1990) and for those economists who put forward alternative interpretations of the entrepreneur (for example, members of the Austrian school represented by Friedrich von Hayek, Ludwig von Mises, and more recently, Kirzner, 1973).

\section{From Economic to Behavioural Science}

Despite some exceptions of entrepreneurship research within the discipline of economics, for a long time entrepreneurship continued to be largely overlooked in economic science models - models often based on a strong equilibrium paradigm in which there seems to be little room for the entrepreneur (Baumol, 1968). In addition, after the Second World War it was important to stimulate individuals to start businesses and get development in society under way, and in the 1950s the availability of entrepreneurial ability was considered a vital factor in economic development. It was tempting to try to find an individual profile leading to entrepreneurial success (or failure). We must also keep in mind that during the war there was a strong development of (and confidence in) psychological instruments that could be helpful in selecting people for certain tasks, for example, to be a fighter pilot, an officer in command and so on. Following this line of thinking, it would be possible to identify and encourage those personalities appropriate to engage in an entrepreneurial career. However, economists could not play a useful role in identifying and developing this ability. Instead, behavioural science researchers, and especially psychologists, saw an open field and increasingly assumed responsibility for continuing the theoretical development on entrepreneurship. The point of departure in this respect was: why do some individuals tend to start their own business whereas others do not? The answer was: it depends on the fact that some individuals have certain qualities that others lack.

\section{David McClelland}

Even though we could find many pioneering exponents for the behavioural approach in entrepreneurship research, perhaps the best-known researcher among behavioural scientists with an interest in entrepreneurship is David McClelland, who was one of the first to present empirical studies in the field of entrepreneurship that were based on behavioural 
science theory. In his pioneering work The Achieving Society (1961), McClelland discussed the question: why are certain societies more dynamic than others? For McClelland, the premise was that the norms and values that prevail in any given society, particularly with regard to the need for achievement $(\mathrm{nACH})$ are of vital importance for the development of the society. By means of a large number of experimentally constructed studies, he demonstrated the link between a country's need for achievement and its economic development. He concluded that countries that are economically more developed are characterized by a stronger focus on institutional norms and openness towards other people and their values, as well as communication between people. It is in this context that entrepreneurs have been recognized as an important driving force for development. Entrepreneurs are people who have a high need for achievement coupled with strong self-confidence, independent problemsolving skills and who prefer situations that are characterized by moderate risk, while accepting individual responsibility.

McClelland was regarded as one of the leading researchers in personality and motivation psychology, and during his career he wrote 16 books and about 185 scientific papers. Best known are his books Personality published in 1951, which was used as a textbook as late as the 1980s, and Human Motivation (1987), in which he summarized much of his thinking on human personality and motivation. (Box I.2.)

Throughout McClelland's career he was guided by his motto 'if something exists, it exists in some amount and can be measured' and that a theory cannot be accepted until tested by rigorous quantitative measurements. In addition, it is possible to identify some salient themes in McClelland's production that characterize his research on human motivation:

\section{BOX I.2 THE CAREER OF DAVID MCCLELLAND}

1917 Born on 20 May in New York, one of five children of a Methodist college president. His religious background (he later became an active Quaker) may explain his interest in solving 'real-world' problems, and his desire to help the socially maladjusted in society

$1942 \quad \mathrm{PhD}$ at Yale University

1941-56 Wesleyan University in Connecticut

1956-87 Professor at Harvard University

1998 Died 27 March 1998 
- a commitment to measurement - everything could be measured and transformed into numbers;

- a fascination with Sigmund Freud and the unconscious - he studied the underlying dimensions in the personality that motivate behaviour, and he believed that the motivations should crystallize into concrete behaviour; and

- a belief that motivations can be changed - during his career he developed different education programmes for altering people's motivational profiles.

McClelland's contributions meant that the personal qualities of the entrepreneur occupied a prominent position in entrepreneurship research during the 1960s and 1970s, and there are a large number of studies that try to identify the particular qualities of the entrepreneur (see summaries in Brockhaus, 1982 and Delmar, 2000), such as the need for achievement, risktaking propensity, locus of control, overoptimism, and desire for autonomy.

\section{... to a Management Science}

After the Second World War, Keynesian economic theory, suggesting increased government interventions to manage cyclical fluctuations, seemed to be working, and there was a positive economic development in society. The importance of entrepreneurship and small businesses seemed to fade away, and many scholars supported Schumpeter's declaration (1942) that 'what we have got to accept is that the large-scale establishment has come to be the most powerful engine of progress' (p. 106). The notion that largescale production and a social order with strong collectivistic elements were conducive to economic development was firmly established among social scientists at the time.

It was in the mid-1970s that the world economy first began to show signs that large systems were not always superior in promoting technological development. The 'twin oil' crises triggered an appraisal of the role of small firms. Many large companies were hit by severe economic difficulties, and unemployment became a major problem in many Western societies. Large companies were increasingly seen as inflexible and slow to adjust to new market conditions. Carlsson (1992) found two explanations for a greater interest in smaller firms: (i) a fundamental change in the world economy, related to the intensification of global competition, the increase in the degree of uncertainty, and greater market fragmentation, and (ii) changes in the characteristics of technological progress. As a consequence, new areas of interest emerged and topics such as entrepreneurship, innovation, industrial dynamics and job generation (Acs, 1992) came to dominate the 
political debate. This development received additional support from politicians such as Ronald Reagan in the US and Margaret Thatcher in the UK, who pursued a policy strongly in favour of promoting small business and entrepreneurship.

\section{David Birch}

It was in this context that entrepreneurship research per se began to develop. David Birch, in his pathbreaking report The Job Generation Process (1979), found that the majority of employment opportunities in the US were created by small and young firms - not large companies. Birch was interested in understanding how jobs were created. The main problem was to obtain adequate data - existing databases were not equipped to cope with large longitudinal data. Birch and his research group used Dun \& Bradstreet data in the US from 1969 to 1976, making considerable efforts to facilitate the analysis of the data over time. The study focused on job creation, and some interesting findings emerged. For example, migration of firms from one region to another played a negligible role, and job losses seemed to be about the same everywhere. Thus, it was not the rate of closures, which varied from one region to another, but rather the rate of job replacements that was crucial for the growth or decline of a region. Birch found that the majority of new jobs were created by firms - often independent and young firms - with 20 or fewer employees. The conclusion was that it was not the large firms in the economy that created new jobs, but the small and young firms.

The report (54 pages) sold only 12 copies; however its influence was enormous, not least on policy makers, but it also had a huge impact on the research community. Although it has been a source of considerable controversy and criticism, it has nevertheless provided the intellectual foundation for research throughout the world to incorporate young and small firms into the analyses of economic development, and many of the findings have been verified in a host of later studies. (Box I.3.)

Birch was not alone in his interest in entrepreneurship and small businesses, a large number of enthusiastic researchers with different backgrounds and different interests began to pour into this new and promising area. The growth of entrepreneurship as an academic field had begun.

\section{The Emergence of an Academic Field}

In the 1980s we can find an increasing interest in entrepreneurship and small business among scholars, especially in management studies, who became 


\section{BOX I.3 THE CAREER OF DAVID BIRCH}

$\begin{array}{ll}1937 & \text { Born 1937 } \\ 1959 & \text { MSc in nuclear reactor design at Harvard University } \\ 1962 & \text { MBA at Harvard University } \\ 1962-66 & \begin{array}{l}\text { Research engineer at the General Astronautics and } \\ \text { Jet Propulsion Laboratory }\end{array} \\ 1966 & \begin{array}{l}\text { PhD in economics at Harvard Business School } \\ 1966-74\end{array} \\ \text { Harvard Business School } \\ 1974-93 & \begin{array}{l}\text { MIT Center for Urban Studies (Director of MIT } \\ \text { Program on Jobs, Enterprises and Markets) }\end{array} \\ 1983-2000 & \text { CEO and President at Cognetics (consulting firm) }\end{array}$

interested in entrepreneurship - leading to the start of a community of entrepreneurship teachers and researchers. This early development was to a high degree characterized by:

- Discovery-orientated research, that is, a focus on providing descriptions and insights about a phenomenon that was previously unfamiliar. The level of methodological sophistication and theoretical analysis in most of the studies was quite low. Churchill (1992) made an analogy with the six blind men and the elephant, stating that it was an unstructured exploration of the elephant - the researchers discovered that this animal was different, that it was composed of a number of unusual parts, and that it was quite large.

- Importation of knowledge, that is, entrepreneurship research had not developed an identity of its own. Instead, it was strongly influenced by the mainstream discipline's terms, concepts, models and methods mainly from scholars with roots in 'management studies'.

- Individualism, that is, the research community was small and fragmented. Entrepreneurship research was, to a great extent, dependent on individual initiatives and projects.

Interestingly, in the early 1990s there was a systematic shift from an interest in the entrepreneur as an individual (entrepreneurial traits) to contextual and processual aspects of entrepreneurship. In this respect, the pioneering work by William Gartner deserves to be mentioned. As early as 1988, Gartner claimed that "Who is the entrepreneur?" is the wrong question', arguing that more relevant questions were "How are new organizations 
created?' (Gartner, 1988). Even if this development towards a processorientated approach has taken time, Gartner's ideas are now firmly anchored within entrepreneurship research.

In addition, since the 1990s we have seen an exponential growth of entrepreneurship research - independent of measures used (number of researchers, articles, conferences and so on) - and we know a lot more today about entrepreneurship than we did 20 years ago. In this respect we can identify some influential trends in the development of entrepreneurship research, for example:

- an influx of more theory-driven approaches;

- a change from fragmentation of research towards specialization (with emerging 'tribes');

- international 'isomorphism' (Aldrich, 2000), including a stronger 'normal science approach' in entrepreneurship research;

- increased internal orientation in research; and

- identifiable research community, role models and core researchers.

\section{History Matters!}

In the development and maturity of entrepreneurship research, with an increased specialization, increased internal orientation, and core research, there is a stronger need for history:

- it is necessary for knowledge accumulation within the field, that is, knowledge accumulation requires an extensive groundwork;

- some topics in entrepreneurship research recur from time to time, and we do not need to invent the wheel every time we start a project; and

- some of the best and most influential works were written in the early days of entrepreneurship research.

In order to move our field forward we need to look backward!!!

\section{A RELATIONAL VIEW TO RESEARCH AND PRACTICE IN ENTREPRENEURSHIP}

Looking at the contributions to the RENT XIX conference in Naples 2005 (Iandoli and Raffa, 2005), the main theme for the conference was 'Entrepreneurship, Competitiveness and Local Development'. The intention of the Scientific Committee was to drive scholars' attention towards the widely acknowledged role played by entrepreneurs and small firms in 
fostering economic development in emerging as well as in developed countries.

Here we want to introduce the conference's main theme and make some comments from recent perspectives to entrepreneurial studies, which see the relationship between entrepreneurs, local context and development in a multidisciplinary and holistic way.

It is well known that the creative and destructive action of entrepreneurs has been considered as one of the main drivers for value creation in the capitalist economy (Schumpeter, 1934) and as the main source for radical innovation in mature markets, when incumbents have exhausted their capability to look for emerging markets (Christensen, 1997). Following such assumptions, recent policies have been developed to promote entrepreneurship as a key leverage for local development. Some models, for example, the 'Learning Region', widely adopted by major international institutions such as the Organisation for Economic Cooperation and Development (OECD) and the European Union are inspired by this vision and based on the following assumptions:

1. regions and territories are required to assume a proactive and autonomous attitude towards the promotion of the growth and development of local industrial systems by exploiting and enhancing local idiosyncratic resources and competencies; and

2. growth is the result of the local capability to construct, develop, foster and integrate local networks of resources, relationships and competencies.

The Learning Region perspective is clearly inspired to the resource-based view - RBV (Barney, 1991; Conner, 1991), in which competitive advantage is related to firms' capability to acquire and develop rare and inimitable resources. Such resources have been classified as natural, infrastructural, technological, financial and human. The RBV criticizes Michael Porter's approach (Porter, 1990), which traces back competitive advantage to structural reasons related to industry characteristics. By reducing the role of structural explanation of competitive advantage, the RBV founds entrepreneurial success on uniqueness and exceptions, including the entrepreneur's subjectivity.

A more recent perspective, the relational view, tries to escape from the juxtaposition between a structural versus individual explanation of competitive advantage, and assumes social networks and relational issues as more comprehensive and crucial competitive factors (Dyer and Singh, 1998). According to the relational view, the analysis of the relationships between firms is a critical research issue for understanding the creation of 
competitive advantage. According to this perspective, firms' relationships are constructed on four potential sources: (i) relation-specific asset; (ii) knowledge-sharing routines; (iii) complementary resources and capabilities; and (iv) effective governance.

Industrial districts, firm clusters and Japanese keiretsu are examples of networks that nurture their competitive advantages on relational assets. Furthermore, the competitiveness of such networks is strongly influenced by location and geographic proximity. In other words, companies belonging to such embedded networks base a significant part of their competitive advantage on their membership to a local business community.

According to Uzzi (1996) firms can be embedded in such networks in which 'the structure and quality of social ties among firms shape economic action by creating unique opportunities and access to those opportunities' (p. 675). The relationship between embeddedness and performance is problematic: if embeddedness is too weak or too strong, then firms experience lower performances, in the former case because they are unable to exploit relational assets, in the latter because excess of embeddedness brings about closure towards novelty and inability to innovate.

In the relational view perspective and by assuming embeddedness as a driver for firm performance, traditional categories of analysis and research subjects need to be reframed in a more systemic way. Many papers presented at the RENT XIX conference, especially those more coherent with the conference theme, appear to be aware of this necessity.

Through a review of the papers accepted for presentation we have looked for both dominant and emerging research issues and tried to reframe them into a holistic view in which social ties, relationships between firms and embeddedness within a local business community represent a possible perspective of analysis to explain the relationship between entrepreneurship and competitiveness. In particular we want to focus readers' attention on the following aspects:

- the local context as socio-geographic entity;

- the importance of knowledge flow and creation in local networks;

- organizational models and management issues for small firms operating within local networks; and

- the role of entrepreneurs within networks.

\section{The Local Context as Socio-geographic Entity}

Research on small business management, especially those adopting an institutionalist view (Scott, 1995), underlines the influence on entrepreneurial 
action of the territory, meant as a social, cultural and geographic whole. Culture, local entrepreneurial tradition, norms and values of a community produce remarkable effects on the motivations and managerial style of entrepreneurs as well as on the ways in which firms interact and aggregate (Becattini, 2000; Rullani, 2002).

It is important to remark that the dependence of small firms on their territory is not only cultural but also structural. Small firms are incomplete economic actors, which depend much more than large companies on the external environment for the acquisition of critical resources, such as professional capabilities, knowledge and financial assets. What matters is that such assets can be better described and understood bearing in mind their relational nature. The strength of the relationship between firms and their territory represents a force that may hinder globalization and internationalization processes.

Papers presented at the RENT conference that may be classified in this research stream focus on the following topics: global entrepreneurship and internationalization, company growth and survival, developing economies, industrial districts and clusters, social capital, supporting policies for small business and the role of regional governments for local development.

\section{The Importance of Knowledge Flow and Creation in Local Networks}

Research on firm networks has investigated the role of knowledge in influencing network performance and individual behaviour. Soda et al. (2004) outline the effects on outcomes of enduring patterns of relationships and comment that 'a past network with its accumulated relational experience becomes a kind of "network memory" that cannot be ignored as it may project a structural overhang over the present, much like a shadow of the past' (p. 893).

Uzzi (1996) relates firm network performance to embeddedness, that is, the capability of a social network to develop dense and strongly interconnected relationships among firms based on mutual trust, reputation, resources sharing and complementarity (Dyer and Singh, 1998). Successful patterns of actions and interactions give rise to tacit knowledge embedded in routines (Nelson and Winter, 1982).

Papers that can be classified in this cluster, representing perhaps the most numerous category, focus on topics such as alliances, interaction with universities and public research (academic spin-off, research-based venture, and so on), regional innovation systems, knowledge sharing in firm networks, start-up, innovation management, network theory and small firms in the extended enterprise. 


\section{Organizational Models and Management Issues for Small Firms Operating within Local Networks}

Small firms are characterized by blurred organizational borders (Raffa and Zollo, 2000) because of their higher dependency on external resources through a number of different ways. In other words, some kinds of resources can be said to belong to a firm with a certain degree of membership. The organizational model of small firms tends to be fuzzy and loosely coupled, and this ensures high organizational flexibility. Adaptation and rapidity are the result of loosely coupled organizational models characterized by a lack of formalization, weak coordination, and strong overlapping between entrepreneurial and managerial behaviours (Hansoff, 1975; Marchini, 1995). Small businesses are themselves networked organizations moving in a wider relational and knowledge network. Such organizational and strategic characteristics make problematic the adoption of traditional management approaches developed in large companies by small firms. Second, the management of a dense network of relationships based on the sharing and exchange of assets requires the development of ad hoc tools and new management attitudes.

Papers that can be classified in this stream deal with the following research subjects: family business, management systems for small firms, knowledge sharing, creation and management, human resource and intellectual capital management, decision making, accounting, planning and control, information technology diffusion, adoption and implementation, and finance (loans, venture capital).

\section{The Role of Entrepreneurs within Networks}

The analysis of entrepreneurs' subjectivity and individual characteristics is a traditional research stream in the small business management research agenda. Actually, in small businesses the entrepreneur plays a major role in shaping organizational lay-out and firm strategy (Schollhammer and Kuriloff, 1979; Stanworth et al., 1989). Both organization and firm strategy are constructed around an entrepreneur's action. Entrepreneurial action develops from an entrepreneur's perception and sense-making of opportunities and threats. Plans, coordination and resource allocation all depend on this perceived world. Firm governance tends to be based more on intuition and entrepreneurial cognition rather than on formalization and planning. As a consequence, decision making is strongly influenced by individual characteristics of entrepreneurs such as traits, motivation, cognitive bias, intuition and gender. Decisions are seldom communicated and discussed with other managers and employees, and entrepreneurs very often tend to centralize both operative and strategic responsibilities. 
Papers that can be classified in this cluster focus on topics such as entrepreneur training and learning, gender and diversity, traits and attitudes, cognitive issues, motivation and leadership.

\section{ENTREPRENEURIAL ACTION IN EMBEDDED LOCAL NETWORKS}

In the embeddedness perspective, the local context, intended as a mix of physical, social and cultural assets, plays a major role in shaping entrepreneurs' behaviour and firm performance. On the other hand, this perspective is not deterministic if one conceives entrepreneurial action as the result of a sensemaking process (Weick, 1979), in which the entrepreneur scans the context, frames environmental clues into opportunities and threats, enacts possible patterns of action and activates accessible resources within the network (Fayolle and Bruyat, 2002; Johannisson, 2002; Stam, 2002). In this way, both objectivist and subjectivist research approaches to entrepreneurship find a higher synthesis that acknowledges the idiosyncratic and situated nature of entrepreneurship, but at the same time considers entrepreneurial behaviour as a combination of structural/social constraints and individual initiative.

By making sense of the local environment, entrepreneurs frame problems in terms of two kinds of critical situations (Capaldo and Iandoli, 2005): those related to the management of the relational assets and those concerning the management of internal assets (Figure I.1).

According to the model proposed in Figure I.1, entrepreneurial action is the construction of satisfying solutions to perceived critical situations.

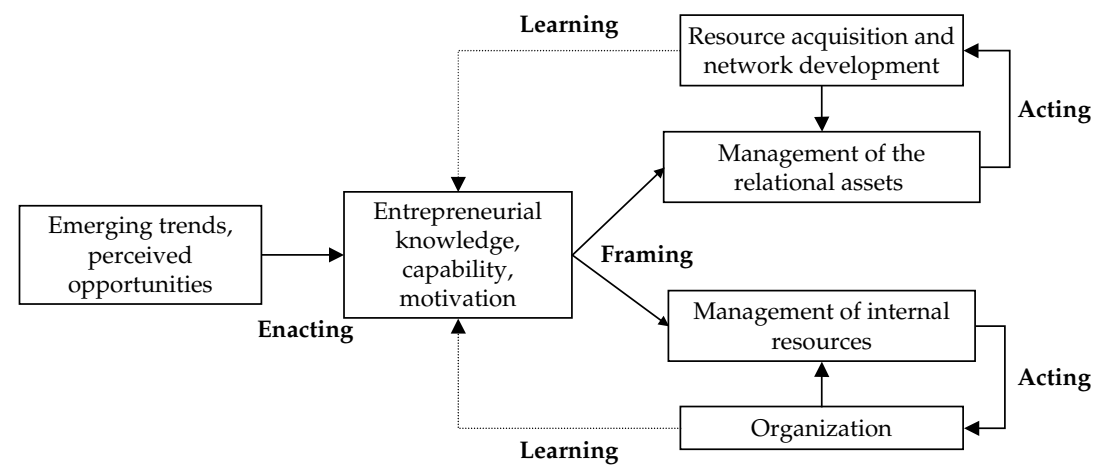

Source: Adapted from Capaldo and Iandoli (2005).

Figure I.1 A model for entrepreneurial action 
Such solutions pertain both to action on the context aimed at managing and developing relational assets, and action on the firm, aimed at allocating and coordinating resources and processes (Davidsson, 2001). Thus, what characterizes entrepreneurial action is not only creativity and opportunity seizing but a variable mix of exploration and administration, whose composition may be influenced by many factors such as an entrepreneur's individual characteristics, cultural issues and structural variables.

In a perspective based on action and sense-making, the distinction between the 'what to do' (strategy) and the 'how to do' (organization) becomes blurred. This lack of distinction explains the loosely coupled character of small-firm organization in which decisional responsibilities and operations are not separated. In such conditions, strategy collapses into action and organization into organizational improvisation (Weick, 1998). Through time, strategy and action in small firms are modelled around predefined or imitable models such as recipes and routines (Nelson and Winter, 1982) and are constrained by an environment perceived as a set of opportunities, threats and accessible resources.

The different theoretical perspectives evoked above and ranging from a knowledge-based theory of the firm (Penrose, 1959; Fransman, 1994; Grant, 1996) to RBV and the relational view can find a possible synthesis into the concept of 'entrepreneurial competence' (Capaldo et al., 2005). Entrepreneurial competence can be defined as the capability of entrepreneurs to face effectively a critical situation by making sense of environmental constraints and by activating relational and internal specific resources.

In a competence-based view of entrepreneurship, the context becomes relevant not only as a set of objective constraints and available resources but also as both an individual construction shaped by an entrepreneur's perceptions and intuitions, and a social construction influenced by embeddedness. Entrepreneurial competence is then the entrepreneur's capability to notice what others do not see but also to exploit embedded relational resources through a mix of openness and embeddedness. For the research purpose, competencies can be assumed as conjectures aimed at explaining superior performance and at describing entrepreneurial behaviour.

As shown by Figure I.1, entrepreneurial action starts from and ends with entrepreneurial competencies. Literature about competence management, developed in other fields such as human resource management, can be evoked to better characterize the concept of entrepreneurial competence in terms of three fundamental dimensions (Boyatzis, 1983): knowledge, skills and motivations. Although several competency models have been proposed in the literature and there is no dominant agreement about competency definition, this proposal can be justified on the basis of the following reasons: 
1. Emphasis on knowledge, intended above all as technical and specialized knowledge, is acceptable given the usual strong involvement of entrepreneurs in technical activities; this is true particularly in emerging and hitech industries where small firms' founders are technical entrepreneurs.

2. Emphasis on skills permits us to take into account the tacit, routine and situated nature of entrepreneurial capabilities. If any work knowledge can be assumed to have a tacit component, the tacit face of the entrepreneurial activity is even more relevant, because such activity is strongly based on action and learning by doing in ill-structured high discretionary work situations, such as the ones usually experienced by entrepreneurs.

3. Motivation has been widely acknowledged as a fundamental element of entrepreneurial behaviour (Stanworth et al., 1989; Davidsson, 1995; Bird, 1989); the proactive nature of entrepreneurial action is based on deep motivational factors ranging from personal characteristics (selfesteem, sense of achievement and so on) to strong social commitment. Motivation, considered as a determinant of action, represents the energy needed to activate and nurture knowledge and skills and to transform them from potentialities to working capabilities. Motivation is the wishful side of entrepreneurial competence.

We think that entrepreneurial competencies can constitute a research object that can attract the interest of scholars with different backgrounds and following different research perspectives or interested in different management or policy issues concerning small business and entrepreneurship. The relational view, thanks to its holistic vision of entrepreneurial behaviour, can favour the convergence and the comparison of different points of view, thus increasing the potential for joint research projects. Finally, managerial implications entailed by a competence-based view of entrepreneurship can attract the attention of practitioners and institutions interested in enhancing and supporting small business development.

\section{ORGANIZATION OF THE BOOK}

The aim of this book is to collect and present the best papers presented at the RENT XIX conference co-organized by the Department of Business and Managerial Engineering - ODISSEO, University of Naples Federico II, ECSB and EIASM, hosted at the University of Naples Federico II on 17-19 November 2005.

Further clarification may be needed at this point about the selection process. More than 250 papers and abstracts from more than 30 countries were submitted to the conference. After a review process performed by the 
members of the Scientific Committee, 131 papers were accepted for presentation with an acceptance rate of about 50 per cent. After the conference a gross list of 45 papers was defined, starting from the recommendation of session chairpersons. These then underwent a first review round managed by the editors of this book, at the end of which 15 were selected and sent out for a second review round to the members of the editorial board. At the end of this stage, 11 were selected and reviewed by the authors. They appear in this book in alphabetical order of first author initial. In the following we introduce them briefly.

In Chapter 1, Fabio Bertoni, Massimo Colombo and Luca Grilli analyse the causality relation between venture capital (VC) financing and growth in the number of high-tech small-firm employees through a longitudinal dataset relating to a sample composed of 537 Italian companies. The results of the econometric analysis performed by the authors strongly support the argument that VC financing spurs firm growth. Conversely, only weak evidence is provided that firm growth leads to a greater likelihood of obtaining VC.

Stijn Bruyneel, Martin Carree and Ludo Peeters (Chapter 2) search for a relation between the employment status of the individual and his or her probability of becoming an entrepreneur. Data from the Belgian Global Entrepreneurship Monitor (GEM) are used in a logistic regression model. It was found that unemployed Belgians were less likely to become an entrepreneur. However, merely claiming that unemployed individuals who are involved in a start-up act out of necessity has been found to be an incomplete account of the decision process. No relationship with age, gender, risk or education emerges from the study.

Gerhard Dijkstra, Ron Kemp and Clemens Lutz (Chapter 3) investigate the relationship between entry barriers and real entry and show that some barriers seem to influence the starter ratio more strongly. Remarkably, from their study it emerges that several of the most important perceived barriers do not restrict real entry rates. This result contains an interesting lesson for policy makers. They should not address important barriers per se, but scrutinize the effects of barriers that seem to restrict real entry.

Rudolf Dömötör and Christopher Hader (Chapter 4) compare traditional entrepreneurial traits and entrepreneurial attitudes with regard to their ability to predict future entrepreneurial behaviour. The practical benefit of such a comparison would be the ability to use these instruments more effectively in predicting future entrepreneurship and in training future entrepreneurs. On the basis of an empirical study the authors show that attitudes represent better predictors of entrepreneurial intent than do entrepreneurial traits. 
Jonas Gabrielsson and Diamanto Politis (Chapter 5) develop theorydriven hypotheses on entrepreneurial decision making and empirically test them on a sample of entrepreneurs in order to increase the understanding of causal and effectual decision making in entrepreneurial settings. They develop exploratory measures to assess the extent to which entrepreneurs are involved in causal and effectual modes of decision making and integrate concepts and models from career theory into the entrepreneurship field to understand how different career motives may guide and constrain future entrepreneurs' decision making.

Petra Gibcus, Pauline de Jong-'t Hart and Ron Kemp (Chapter 6) examine the determinants of growth of start-ups in the Netherlands by distinguishing between environmental and internal determinants (entrepreneurial and organizational) of growth through a longitudinal dataset containing 10 years of information on start-ups. Their study shows that several determinants seem to have a positive effect on growth, among which are the ambition to expand, unfulfilled needs, networking and organizational learning through employees.

Siri Terjesen and Colm O'Gorman (Chapter 7) explore female involvement in the supply of, and demand for, new venture finance in Ireland in order to understand whether there are differences in the financing of new ventures planned by female and male nascent entrepreneurs. Given the paucity of research on female entrepreneurship activity, they report the demographic profiles and aspects of personal context of the entrepreneurs and informal investors and seek to explain why it is that Irish females, as compared to Irish males, have a lower demand for entrepreneurial finance and are less involved in informal investment activity.

Lorraine Uhlaner and Jerry van Santen (Chapter 8) examine the relationship between organization contextual variables and knowledge management (KM) practices in small and medium-sized enterprises (SMEs). The proposed research model is explored empirically using a sample of 16 Dutch technology-based SMEs. Size and membership with a trade organization and/or having a large supplier are all found to predict certain KM practices. In contrast to expectations, a strong positive relationship is found between the family business variable and certain enabling practices. A positive relationship is found especially between degree of formalization of capturing and locating practices and quality performance.

Bram Wauters and Johan Lambrecht (Chapter 9) focus on refugee entrepreneurship. The aim of this chapter is to examine the current situation regarding refugee entrepreneurship in Belgium. The authors tested five motivational theories for becoming an entrepreneur among refugees and found that the main motive was hope of facilitating integration into the host society. Reasons that also apply to native entrepreneurs, such as being one's 
own boss (the entrepreneur model), also score high. Negative motives (a way out of unemployment) score low in this form of self-reporting.

Friederike Welter, David Smallbone, Nina Isakova and Elena Aculai (Chapter 10) explore similarities and differences between male and female entrepreneurs, and their businesses and strategies in different transition environments. Their analysis illustrates that in a transition context there are more similarities than differences, essentially because the difficult nature of the external environment facing entrepreneurs is a dominant influence. Overall, the results emphasize the need to look at entrepreneurship within its social and economic context, which also might explain differences that are often taken as gender related.

Frits Wijbenga, Theo Postma and Rebecca Stratling (Chapter 11) propose a multi-theoretical approach to investigate the role of venture capitalists (VCs) in the strategy development and evaluation process of the entrepreneurial firm and to understand whether the VC enhances the entrepreneurial firm's control systems and accordingly contributes to entrepreneurial firm performance. The results indicate that VCs play an enabling role for effective use of firms' control systems, facilitating stability and efficiency. Furthermore, VC services facilitate the entrepreneurial firm's utilization of cost control and incentive and reward systems and have an indirect effect on organizational performance. The results also suggest that VCs tend to pay too little attention to the establishment of quality systems in entrepreneurial firms.

\section{ACKNOWLEDGEMENTS}

We wish to thank Odd Jarl Borch, Hermann Frank, Bengt Johannisson, Asko Miettinen, Monder Ram, Peter Rosa, David Smallbone and Friederike Welter for their valuable work as reviewers of the contributions contained in this book - their efforts have definitely contributed to raising the overall quality standard.

Moreover, we wish to thank Asko Miettinen (Tampere University of Technology), Antti Paasio (Turku School of Economics, Finland), David Smallbone (Kingston University, UK), Roy Thurik (Erasmus Universiteit Rotterdam, The Netherlands), Gerry Van Dyck (EIASM, Brussels, Belgium) and José M. Veciana (Universidad Autonoma de Barcelona, Spain), members of the RENT 2005 Scientific Committee, for their valuable work in selecting the 131 papers accepted for presentation at the conference, which represented the starting-point for the preparation of this book. 


\section{REFERENCES}

Acs, Z.J. (1992), 'Small business economics: a global perspective', Challenge, 35, $38-44$.

Aldrich, H.E. (2000), 'Learning together: national differences in entrepreneurship research', in D.L. Sexton and H. Landström (eds), The Blackwell Handbook of Entrepreneurship, Oxford: Blackwell, pp. 5-25.

Barney, J.B. (1991), 'Firm resources and sustained competitive advantage', Journal of Management, 17, 99-120.

Baumol, W.J. (1968), 'Entrepreneurship in economic theory', American Economic Review, 58 (2), 64-71.

Baumol, W.J. (1990), 'Entrepreneurship: productive, unproductive and destructive', Journal of Political Economy, 98 (5), 893-921.

Becattini G. (2000), Il distretto industriale, Turin: Rosenberg \& Sellier.

Birch, D.L. (1979), The Job Generation Process, Cambridge, MA: MIT Program on Neighborhood and Regional Change.

Bird, B. (1989), Entrepreneurial Behavior, Glenview, IL: Scott Foresman \& Co.

Boyatzis, R.E. (1983), The Competent Manager, New York: Wiley.

Brockhaus, R. (1982), 'The psychology of the entrepreneur', in C.A. Kent, D.L. Sexton and K.H. Vesper (eds), Encyclopedia of Entrepreneurship, Englewood Cliffs, NJ: Prentice-Hall, pp. 39-71.

Capaldo, G. and L. Iandoli (2005), 'Un apporccio metodologico basato sulle competenze per la rilevazione dei fabbisogni formativi nelle piccole imprese', in G. Capaldo, L. Iandoli and P. Montobbio (eds), Piccole Imprese e Competenze, Naples: ESI, pp. 15-24.

Capaldo, G., L. Iandoli and C. Ponsiglione (2005), 'Entrepreneurial competencies and training needs of small firms: a methodological approach', Piccola Impresa/Small Business, 2, 115-35.

Carlsson, B. (1992), 'The rise of small business: causes and consequences', in W.J. Adams (ed.), Singular Europe: Economy and Policy of the European Community after 1992, Ann Arbor, MI: University of Michigan Press, pp. 145-69.

Christensen, C.M. (1997), The Innovator's Dilemma, Boston, MA: Harvard Business School Press.

Churchill, N.C. (1992), 'Research issues in entrepreneurship', in D.L. Sexton and J.D. Kasarda (eds), The State of the Art of Entrepreneurship, Boston, MA: PWS-Kent, pp. 579-96

Conner, K.R. (1991), 'A historical comparison of resource-based theory and five schools of thought within industrial organization economics: do we have a new theory of the firms?', Journal of Management, 17, 121-54.

Dahmén, E. (1950), Svensk industriell företagsverksamhet, Stockholm: IUI.

Davidsson, P. (2001), 'Towards a paradigm for entrepreneurship research', paper presented at the RENT XV conference, Turku, 22 November.

Delmar, F. (2000), 'The psychology of the entrepreneur', in S. Carter and D. JonesEvans (eds), Enterprise and Small Business, Harlow: Pearson Education, pp. 132-54.

Dyer, J.H. and H. Singh (1998), 'The relational view: cooperative strategy and sources of interorganizational competitive advantage', Academy of Management Review, 23 (4), 660-79.

Fayolle, A. and C. Bruyat (2002), 'A conceptual and methodological framework to study, using the modelling of complex system, the foundation and the develop- 
ment processes of innovative business activities', paper presented at the RENT XVI conference, Barcelona, 21-22 November.

Fransman, M. (1994), 'Information, knowledge, vision and theories of the firm', Industrial and Corporate Change, 3 (2), 1-45.

Gartner, W.B. (1988), "'Who is an entrepreneur?" is the wrong question', American Journal of Small Business, Spring, 11-32.

Grant, R.M. (1996), 'Toward a knowledge-based theory of the firm', Strategic Management Journal, 17, 109-22.

Hansoff, H.I. (1975), 'The state of practice in management systems', Working Paper 75, EIASM, Brussels.

Iandoli, L. and M. Raffa (2005), Entrepreneurship, Competitiveness and Local Development, Naples: Edizioni Scientifiche Italiane.

Johannisson, B. (2002), 'Entrepreneurship as breaking and making sense-learning beyond boundaries', paper presented at the RENT XVI conference, Barcelona, 21-22 November.

Keynes, J.M. (1936 [1973]), General Theory of Employment, Interest and Money, New York: Harcourt Brace.

Kirzner, I.M. (1973), Competition and Entrepreneurship, Chicago: Chicago University Press.

Knight, F.H. (1916 [1921]), Risk, Uncertainty and Profit, New York: Houghton Mifflin.

Landström, H. (2005), Pioneers in Entrepreneurship and Small Business Research, New York: Springer.

Leibenstein, H. (1968), 'Entrepreneurship and development', American Economic Review, 58, 72-83.

Marchini, I. (1995), Il governo della piccola impresa, Vols I and II, Urbino: Aspi/InsEdit.

McClelland, D.C. (1951), Personality, New York: Holt, Rinehart \& Winston.

McClelland, D.C. (1961), The Achieving Society, Princeton, NJ: van Nostrand.

McClelland, D.C. (1987), Human Motivation, Cambridge: Cambridge University Press.

Nelson, R.R. and S.G. Winter (1982), An Evolutionary Theory of Economic Change, Cambridge, MA: The Belknap Press of Harvard University Press.

Penrose, E.T. (1959), The Theory of the Growth of the Firm, Oxford: Basil Blackwell.

Porter, M. (1990), The Competitive Advantage of Nations, New York: Free Press.

Raffa, M. and G. Zollo (2000), Economia del software. Elementi introduttivi, Naples: Edizioni Scientifiche Italiane.

Reisman, D. (2004), Schumpeter's Market: Enterprise and Evolution, Cheltenham, UK and Northampton, MA, USA: Edward Elgar.

Rullani, E. (2002), 'Il distretto industriale come sistema adattivo complesso', in Quadrio Curzio and M. Fortis (eds), Complessità e Distretti Industriali, Bologna: Il Mulino, pp. 65-110.

Schollhammer, H. and A.H. Kuriloff (1979), Entrepreneurship and Small Business Management, Chichester: Wiley.

Schumpeter, J.A. (1912), Theorie der Wirtschaftlichen Entwicklung, Leipzig: Duncker \& Humblot.

Schumpeter, J.A. (1934), The Theory of Economic Development, Cambridge, MA: Harvard University Press.

Schumpeter, J.A. (1942), Capitalism, Socialism and Democracy, New York: Harper \& Row. 
Scott, W.R. (1995), Institutions and Organizations: Foundations for Organizational Science, Thousand Oaks, CA: Sage.

Smith, A. (1776 [1994]), The Wealth of Nations, E. Cannan (ed.), New York: Modern Library.

Soda, G., A. Usai and A. Zaheer (2004), 'Network memory: the influence of past and current networks on performance', Academy of Management Journal, 47 (6), 893-906.

Stam, E. (2002), 'Theorizing entrepreneurship in context', paper presented at the RENT XVI conference, Barcelona, 21-22 November.

Stanworth J., S. Blythe, B. Granger and C. Stanworth (1989), 'Who becomes an International entrepreneur?', Small Business Journal, 8 (1), 11-22.

Swedberg, R. (1994), Schumpeter: Omskapande förstörelse och entreprenörskap, Stockholm: Ratio.

Uzzi, B. (1996), 'The sources and consequences of embeddedness for the economic performance of organizations', American Sociological Review, 61, 674-98.

Weick, K.E. (1979), The Social Psychology of Organization, 2nd edn, Reading, MA: Addison Wesley.

Weick, K.E. (1998), 'Improvisation as a mindset for organizational analysis', Organization Science, 9 (5), 543-55.

Wennekers, S. and R. Thurik (1999), 'Linking entrepreneurship and economic growth', Small Business Economics, 13 (1), 27-55. 